\title{
NAD Precursors as Antiteratogens Against Aminothiadiazole ${ }^{1}$
}

\author{
ALLAN R. BEAUDOIN \\ Department of Anatomy, The University of Michigan, \\ Ann Arbor, Michigan 48104
}

\begin{abstract}
The teratogen 2-amino-1,3,4-thiadiazole (ATDA) is an antagonist of nicotinamide, and may act by interfering with the synthesis or utilization of the coenzyme nicotinamide adenine dinucleotide (NAD). Several compounds that can be converted to NAD were tested as antiteratogens against ATDA. At day 11 of gestation (sperm day = day 0) pregnant Wistar-derived rats were given single ip injections of ATDA $(100 \mathrm{mg} / \mathrm{kg})$, or ATDA immediately followed by the suspected antiteratogen ip or by gavage, or the antiteratogen alone. Compounds tested were NAD, nicotinamide, nicotinic acid, quinolinic acid, kynurenine sulfate, and L-tryptophan, in doses of 10-200 mg per animal. At autopsy (day 20) fetuses were recovered and examined. It was found that each antiteratogen significantly reduced the frequency of ATDAinduced resorptions and malformations. At certain doses each antiteratogen gave complete protection against ATDA-induced malformations in some, but not all, litters. These results support the hypothesis that ADTA interferes with the synthesis or utilization of NAD and suggest that substances converted to NAD act as antiteratogens against ATDA.
\end{abstract}

Treatment of pregnant rats with 2 -amino-1,3,4-thiadiazole (fig. 1) induces malformations in their offspring (Maren and Ellison, '72; Scott et al., '72; Beaudoin, '72, '73). Recently Mizutani et al. (74) demonstrated the amino acid tryptophan to be an antiteratogen to aminothiadiazole. Both nicotinamide and tryptophan can be converted in the body to the coenzyme nicotinamide adenine dinucleotide (NAD).

The present investigation was undertaken to determine if NAD and other substances, which can be converted to NAD (fig. 2), are antiteratogens to aminothiadiazole.

\section{MATERIALS AND METHODS}

Virgin female Wistar-derived rats from my colony were used. The animals were

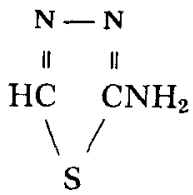

Fig. 1 Structural formula of 2-amino-1,3,4-thiadiazole. maintained on Teklad Rat Diet (Teklad Mills, Winfield, Iowa) ad libitum with supplemental feedings of lettuce. The day of finding sperm in the vaginal smear was designated day 0 of pregnancy. 2-Amino1,3,4 - thiadiazole hydrochloride (ATDA) (Eastman Kodak, Rochester, New York) was administered as a $2 \%$ aqueous solution ip at $10 \mathrm{AM}$ on day 11 of gestation, $100 \mathrm{mg} / \mathrm{kg}$ maternal body weight. The suspected antiteratogens were used in doses of 10-200 mg per animal, administered either ip or by gavage, immediately following the injection of ATDA. The following compounds were tested for antiteratogenic activity: nicotinamide, in $\mathrm{H}_{2} \mathrm{O} ; \mathrm{NAD}$, in $\mathrm{H}_{2} \mathrm{O}$; L-tryptophan, in $0.4 \mathrm{M} \mathrm{Na}_{2} \mathrm{CO}_{3}$; quinolinic acid, in sesame oil; L-kynurenine sulfate, in $\mathrm{H}_{2} \mathrm{O}$ and nicotinic acid, in $1 \mathrm{~N}$ $\mathrm{NaHCO}_{3}$. Each compound was prepared so that the single dose to be administered was contained in 1 or $2 \mathrm{ml}$ of solution.

Pregnancy was terminated at day 20 and resorption sites were counted and the fetuses recovered, weighed, and fixed in Bouin's fluid for subsequent examination

Received July 31, '75. Accepted Oct. 28, '75.

I Supported by NIH Grant HDO0400. 


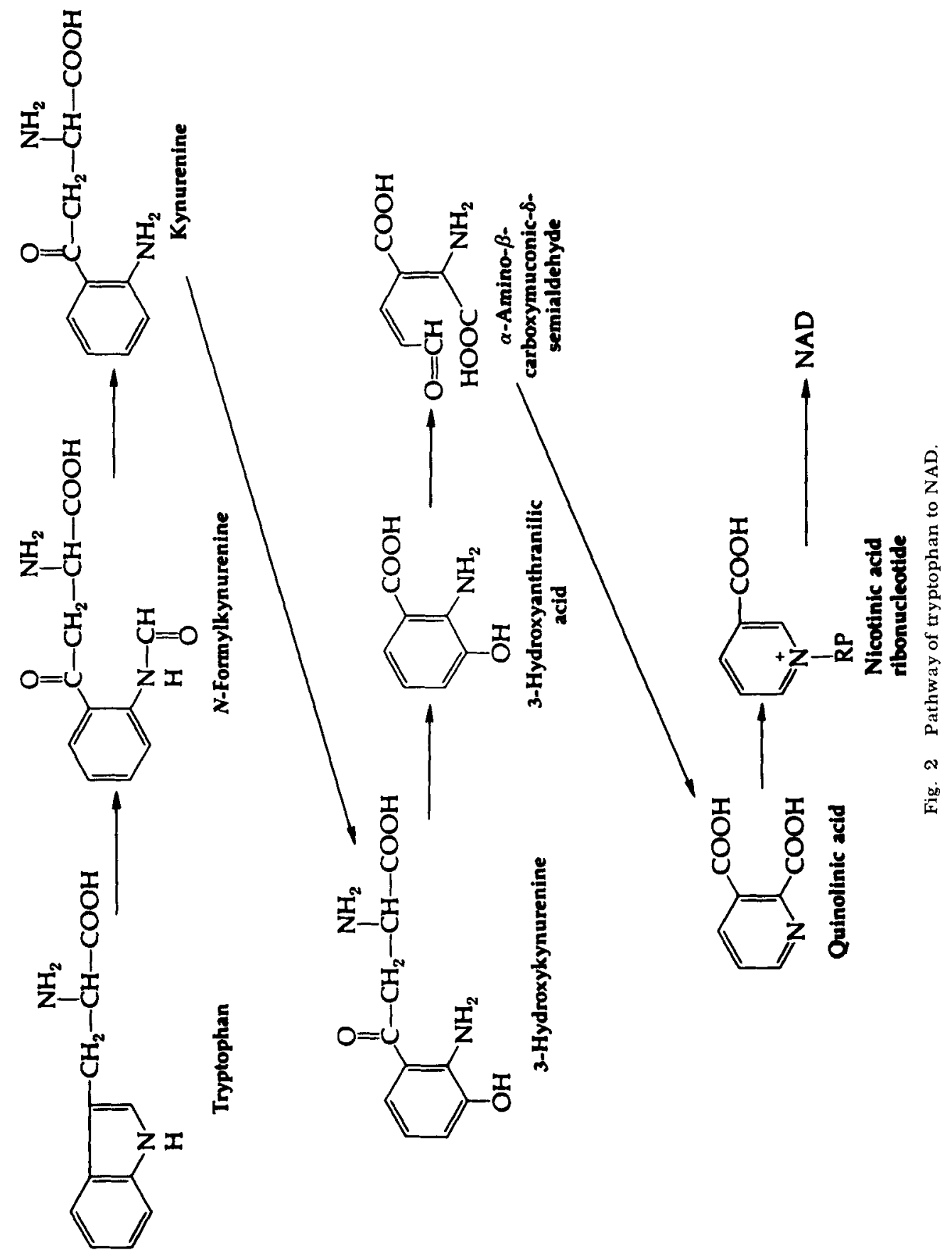


for malformations. Placentae were also recovered and weighed.

\section{RESULTS}

Single ip injections of ATDA at day 11 induced several different malformations (table 1). The tail was the organ most susceptible, being abnormal in $97.4 \%$ of the malformed survivors. Tail length, in experimental fetuses having tails, ranged from $0.1-0.7 \mathrm{~cm}$, compared with $1.3-1.5 \mathrm{~cm}$

TABLE 1

Aberrant development following injection $100 \mathrm{mg} /$ kg ATDA at day 11 of gestation

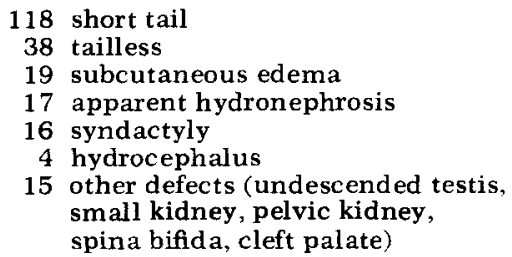

Total $=160 / 169$ surviving fetuses in control fetuses. Only fetuses with kidneys lacking renal papillae (grade 0 of Woo and Hoar, '72) were included in the category "apparent hydronephrosis." The permanency of this condition has been questioned (Woo and Hoar, '72). It is also possible that subcutaneous edema and undescended testis are transistory conditions.

Nicotinamide, NAD, tryptophan, kynurenine, quinolinic acid, and nicotinic acid all acted as antiteratogens against aminothiadiazole (table 2). Each supplement reduced the frequency of implantation sites resorbed and of survivors malformed. Thiadiazole-induced fetal weight loss was also prevented by each supplement. Complete protection was afforded the embryos of all litters by nicotinamide, NAD, and nicotinic acid, whereas tryptophan, kynurenine, and quinolinic acid did allow some malformations to occur, but at a very low frequency. It is noteworthy that even these 3 compounds gave complete protection to some litters.

Table 3 presents data for the effect of

TABLE 2

The effect of nicotinamide, NAD, and tryptophan and some of its metabolites on the teratogenicity of ATDA following ip injection at day 11 of gestation

\begin{tabular}{|c|c|c|c|c|c|}
\hline $\begin{array}{c}\text { A TDA } \\
(100 \mathrm{mg} / \mathrm{kg})\end{array}$ & $\begin{array}{c}\text { No. } \\
\text { rats } \\
\text { injected }\end{array}$ & $\begin{array}{c}\text { Total } \\
\text { implantation } \\
\text { sites }\end{array}$ & $\begin{array}{c}\% \\
\text { Resorbed }\end{array}$ & $\begin{array}{c}\%_{c} \\
\text { Survivors } \\
\text { malformed }\end{array}$ & Fetal weight \\
\hline & 24 & 270 & 37.5 & 94.6 & $\begin{array}{c}\text { mean } \pm S D \\
2.54 \pm 0.65\end{array}$ \\
\hline + $50 \mathbf{m g}$ nicotinamide & 9 & 122 & 6.5 & $\mathbf{0}$ & $4.12 \pm 0.65$ \\
\hline$+50 \mathrm{mg}$ NAD & 11 & 140 & 6.4 & 0 & $4.11 \pm 0.54$ \\
\hline + $100 \mathrm{mg}$ tryptophan & 9 & 102 & 7.8 & 4.31 & $4.40 \pm 0.70$ \\
\hline$+100 \mathrm{mg}$ kynurenine & 11 & 127 & 11.8 & $2.6^{2}$ & $3.86 \pm 0.69$ \\
\hline + $200 \mathrm{mg}$ quinolinic acid & 11 & 139 & 14.4 & 15.93 & $3.84 \pm 0.88$ \\
\hline$+100 \mathrm{mg}$ nicotinic acid & 8 & 102 & 3.9 & 0 & $4.39 \pm 0.89$ \\
\hline
\end{tabular}

1 Two fetuses with hooked tail, 3 with subcutaneous edema; only 3 litters affected.

2 Two fetuses with ectrodactyly, 1 with short tail; only 2 litters affected.

3 Eighteen fetuses with short tails, 2 with diaphragmatic hernia, 1 with syndactyly; only 2 litters affected.

TABLE 3

Dosage effect on L-tryptophan on the teratogenicity of ATDA

\begin{tabular}{|c|c|c|c|c|c|}
\hline \multicolumn{2}{|c|}{ Day-11 treatment } & \multirow{2}{*}{$\begin{array}{c}\text { No. } \\
\text { rats } \\
\text { injected }\end{array}$} & \multirow{2}{*}{$\begin{array}{c}\text { Total } \\
\text { implantation } \\
\text { sites }\end{array}$} & \multirow{2}{*}{$\begin{array}{c}\% \\
\text { Resorbed }\end{array}$} & \multirow{2}{*}{$\begin{array}{c}\% \\
\text { Survivors } \\
\text { malformed }\end{array}$} \\
\hline ATDA & Tryptophan & & & & \\
\hline $100 \mathrm{mg} / \mathrm{kg}$ & 0 & 24 & 270 & 37.5 & 94.6 \\
\hline $100 \mathrm{mg} / \mathrm{kg}$ & $10 \mathrm{mg}$ & 8 & 85 & 17.5 & 41.4 \\
\hline $100 \mathrm{mg} / \mathrm{kg}$ & $25 \mathrm{mg}$ & 10 & 109 & 8.2 & $19.0^{1}$ \\
\hline $100 \mathrm{mg} / \mathrm{kg}$ & $50 \mathrm{mg}$ & 10 & 114 & 11.4 & 4.9 \\
\hline $100 \mathrm{mg} / \mathrm{kg}$ & $100 \mathrm{mg}$ & 9 & 102 & 7.1 & 0 \\
\hline 0 & 50 and $100 \mathrm{mg}$ & 6 & 72 & 12.5 & 0 \\
\hline
\end{tabular}

1 Only 3 litters affected; 19 fetuses with short tails. 
different doses of tryptophan on the teratogenic action of ATDA. Each dose studied reduced the frequency of resorptions, but dose dependency was not established. However, the protective effect of tryptophan against malformations was dose dependent.

\section{DISCUSSION}

Aminothiadiazole is an antagonist of nicotinamide. Supplemental nicotinamide treatment protected rat fetuses from the embryolethal and teratogenic effects of ATDA; and also abolishes the toxic and antitumor effect of the drug in mice (Shapiro et al., '57; Humphreys et al., '62), and prevents the uricogenic effect of ATDA in human beings (Krakoff and Balis, '59). Since the usual fate of nicotinamide in the body is incorporation into NAD or its phosphate (NADP) it has been suggested that ATDA may interfere with the synthesis or utilization of $\mathrm{NAD}(\mathrm{P})$ in cellular metabolism (Beaudoin, '74).

The energy requirements of animal cells are met by the oxidation of organic compounds. NAD is the coenzyme most often used in the reaction sequences leading to the production of energy (White et al., '73). It is not difficult to envision a depletion of cellular energy leading to diminished cellular activity, culminating in cell death. Diminished cellular metabolic activity, as expressed by depression of DNA synthesis, has been described in rat embryos from ATDA-treated mothers (Scott et al., '73). Cell death was also noted by the same authors in limb buds prior to expression of ATDA-induced limb malformations; and cell death was found in the neural tube of rat fetuses preceding the appearance of ATDA-induced central nervous system defects (Beaudoin, 74). Other teratogens have also been reported to act by interfering with NAD functions, and the suggestion has been made that these nicotinamide-sensitive teratogens exert their effects by disrupting pathways of energy metabolism requisite for normal growth and development (Landauer and Wakasugi, '68; Caplan, '72). The maintenance of cellular energy levels, as with the supplemental treatment described in this paper, would prevent the effects ascribed to energy deficiency, and enable development to proceed normally.
The results of this experiment have shown NAD, nicotinamide, and tryptophan and its metabolites to act as antiteratogens against ATDA. Tryptophan and its metabolites presumably are effective because they, like nicotinamide, can be converted to the coenzyme NAD. These experiments support the conclusion that ATDA acts specifically on the synthesis or utilization of NAD and suggest that any substance capable of being converted to NAD can protect embryos against the lethal and teratogenic effects of ATDA. Investigation of NAD-dependent reactions may indicate which reaction(s) is involved in aminothiadiazole teratogenesis.

\section{LITERATURE CITED}

Beaudoin, A. R. 1972 Teratogenic action of 2amino-1,3,4-thiadiazole in rats. Teratology, 5: 250 (abst.).

1973 Teratogenic activity of 2-amino1,3,4-thiadiazole hydrochloride in Wistar rats and the protection afforded by nicotinamide. Teratology, $7: 65-72$.

_ 1974 Thiadiazole-induced myelodysplasia in rats. Ter atology, $9: 179-190$.

Caplan, A. I. 1972 Comparison of the capacity of nicotinamide and nicotinic acid to relieve the effects of muscle and cartilage teratogens in developing chick embryos. Dev. Biol., 28: 344-351.

Humphreys, S. R., J. M. Venditti, C. J. Ciotti, I. Kline, A. Goldin and N. O. Kaplan 1962 Toxicity and antileukemic effectiveness of pyridine derivatives and 1,3,4-thiadiazole derivatives in mice. Relationship to nicotinamide antagonism. Cancer Res., 22: 483-550.

Krakoff, I. H., and M. E. Balis 1959 Studies of the uricogenic effect of 2-substituted thiadiazole in man. J. Clin. Inv., 38: 907-915.

Landauer, W., and N. Wakasugi 1968 Teratological studies with sulphonamides and their implications. J. Embryol. Exp. Morph., 20: 261284.

Maren, T. H., and A. C. Ellison 1972 The teratological effect of certain thiadiazoles related to acetazolamide, with a note on sulfanilamide and thiazide diuretics. Johns Hopkins Med. J., 130: 95-104.

Mizutani, M., T. Ihara and T. Sugitani 1974 Protective effects of nicotinamide and tryptophan against the ter atogenicity of $N, N^{\prime}$-methylene-bis (2-amino-1,3,4-thiadiazole) in the hamster. Ter atology, 9: 28A (abst.).

Scott, W. J., E. J. Ritter and J. G. Wilson 1973 DNA synthesis inhibition, cytotoxicity and their relationship to teratogenesis following administration of a nicotin amide antagonist, aminothiadiazole, to pregnant rats. J. Embryol. Exp. Morph., 30: 257-266.

Scott, W. J., J. G. Wilson and E. J. Ritter 1972 The teratogenic, biochemical and histological effects of aminothiadiazole and their reversibility by nicotinamide. Teratology, 5: 266 (abst.).

Shapiro, D. M., M. E. Shils, R. A. Fugmann and 
I. M. Friedland 1957 Quantitative biochemical differences between tumor and host as a basis for cancer chemotherapy. IV. Niacin and 2-ethylamino-1,3,4-thiadiazole. Cancer Res., 17: 29-33.

White, A., P. Handler and E. L. Smith 1973
Principles of Biochemistry. McGraw-Hill, New York.

Woo, D. C., and R. M. Hoar 1972 "Apparent hydronephrosis" as a normal aspect of renal development in late gestation of rats: the effect of methyl salicylate. Teratology, 6; 191-200. 